\title{
ASPECTOS DA NARRATIVA DE RESISTÊNCIA NA LITERATURA E NO CINEMA
}

\author{
VeridianaValente PINHEIRO \\ Campus Universitário de Abaetetuba/UFPA \\ veranahum@hotmail.com \\ Tânia SARMENTO-PANTOJA \\ Campus Universitário de Abaetetuba/UFPA \\ nicama@ufpa.br
}

Resumo: Com o objetivo de observar as ressonâncias de um determinado período histórico/cultural, o da ditadura militar de 1964, o trabalho em questão parte da relação entre literatura e cinema e de seus efeitos, na composição do romance Em Câmera lenta (1977), do paraense Renato Tapajós.

Palavras-chave: Literatura. Cinema. Narrativa de resistência. Renato Tapajós.

\begin{abstract}
Aiming to observe some historical and cultural resonances of 1964 Brazilian Military Dictatorship, this work parts from the relation between literature and cinema and its effects in the composition of novel Em camera lenta (1977), by the Brazilian writer Renato Tapajós.
\end{abstract}

Keywords: Literature. Cinema. Narrativa of resisstance. Renato Tapajós.

\section{Considerações iniciais ${ }^{1}$}

Tomo a relação entre literatura e cinema como fundamento para analisar a composição do romance Em Câmera lenta (1977), do paraense Renato Tapajós, em particular, como os efeitos dessa relação ligados à constituição das impressões de realidade se articulam com vistas a remeter a um determinado aspecto da história do país: o regime militar de 1964 e os mecanismos de repressão impostos aos indivíduos ligados à resistência.

Michel Foucault analisa a repressão como sendo uma poderosa "mecânica do poder", tratando-o como uma questão propriamente histórica, como podemos perceber no fragmento a seguir: "se falam com tal profusão e há tanto tempo, é por que essa repressão está bastante firmada, possui raízes sólidas, pesa sobre o sexo de maneira tão rigorosa" (FOUCAULT, 1988, p. 15). Para esclarecer melhor o que entendo como sendo tais mecanismos repressivos, tomo o conceito foucaultiano de dispositivo, tal qual encontramos em suas obras a História da Sexualidade e a

\footnotetext{
${ }^{1} \mathrm{O}$ presente trabalho é fruto das investigações realizadas nos projetos de pesquisa Narrativa de Resistência: Formas, Performances e trajetos na Amazônia; Leituras da Ditadura: Discursos ficcionais e não-ficcionais da resistência ao Regime Militar de 1964, ambos coordenados pela Profa. Tânia Sarmento-Pantoja. Especiais agradecimentos são dirigidos a Katyane Cabral Marinho, Graduada em Letras e voluntária no segundo projeto referido, a minha orientadora Tânia Sarmento- Pantoja, ao professor colaborador Augusto Sarmento, ao Carlos Augusto Carneiro Costa mestrando em Literatura da USP - Universidade do estado de São Paulo
} 
Microfísica do Poder ${ }^{2}$. Inicialmente, dispositivo aparece em História da sexualidade, como traço essencial que permite ao analista estabelecer relações entre poder, sexo e a história do ocidente. Posteriormente, se faz presente em Microfisica do Poder, para dar conta de como se constituem os aparatos jurídicos do tribunal, das prisões e das punições cotidianas, refletindo como tais aparatos moldam as estruturas cognitivas do sujeito, com vistas a disciplinar o individuo para a vida em sociedade. Funcionando como instrumento de análise os dispositivos são as estratégias, as estruturas, os mecanismos e as ferramentas de coerção e disciplina.

Dessa forma, o poder assume aspectos repressivos, na medida em que aparecem processos de rupturas que visam a negação do poder. Nesse sentido, é da historicidade citada anteriormente que destaco determinados aspectos repressivos, como as prisões, as torturas, os assassinatos e as perseguições policiais que comprometiam a integridade moral, física e psicológica dos militantes de esquerda, que realizaram a resistência ao regime ditatorial de 64 e que se fazem presentes na narrativa de Em câmera lenta.

\section{0 lento olhar em câmera sobre a coerção e a disciplina}

Em Câmera Lenta tem inicio, com apresentação de um discurso autoral-biográfico e apresenta também uma síntese do romance, salientando as principais discussões abordadas, entre elas, aspectos morais e políticos são apresentados na narrativa e a forma como o romance denuncia a violência repressiva e a tortura vivida pelos militantes de esquerda no período da ditadura de 1964.

Em uma primeira incursão da obra, tomei como ponto de partida o título da narrativa. Sua sugestividade através do titulo Em Câmera Lenta, propõe desenvolver a idéia de que dará sentido a um conjunto de aspectos ocorridos, a partir de um viés histórico. Assim, quando analisamos a expressão "em câmera" descobrimos a ação que circula a narrativa, reforçada pela escolha da preposição "em", que auxilia na demonstração, de forma simbólica, do movimento da câmera cinematográfica, que podemos conceber como: "um olho pelo fato de, de maneira objetiva, registrar o mundo pró-filmico sem transformá-lo. “[...] é um nome para a maneira como olhamos e como conhecemos a um dado momento" (AUMONT, 2003. p. 40-41). Nesse sentido, a

\footnotetext{
${ }^{2} \mathrm{Em}$ suma o dito e o não dito são os elementos do dispositivo. O dispositivo é a rede que se pode estabelecer entre estes elementos (FOUCAULT, 1989. p. 244)
} 
"câmera" se coloca na narrativa como instrumento de projeção do real, que será desvelado através do olhar revolucionário do personagem Ele. O adjetivo "lenta", é assim entendido como algo que procede um acontecimento de forma desacelerada, moldando o olhar do narrador focalizador, que se produz "em câmera".

Como já dito a narrativa do romance parte de uma simulação: uma voz autoral bio-gráfica que finge ser o autor do romance dá início à narrativa. A técnica narrativa utilizada para constituir essa voz é a do narrador focalizador ${ }^{3}$, que assume duas focalizações: a primeira é a partir do olhar do personagem Ele, em que a voz é propriamente autoral, a segunda é a partir do olhar do pai da personagem Ela. Esses sujeitos da focalização encadeiam-se, assumindo ora um, ora outro a voz do discurso, ou seja, além de encadeados esses "olhares" se deixam perceber como se fosse um olhar através de uma câmera cinematográfica.

No primeiro capitulo é apresentada a cena de um confronto urbano contra a policia em que o líder é atingido e uma companheira é pega pelos militares. O militante ferido é levado para um aparelho ${ }^{4}$, como descrito no seguinte fragmento:

Se eles vierem e atirarem as balas pegarem no peito, na cabeça. [...] agora não dá mais para fazer nada nem por ela nem por ninguém e o que fecha a garganta é o cerco, as armas sem nome, as mãos sem nome, as peles vazias que se movem como se fossem gente, o isolamento; cada dia mais perto, há quinze dias nunca admitiria isso, embora já o soubesse há muito tempo [...] Nada deu certo [...] mas pouca gente entendeu, nem podia entender e agora estamos sozinhos, vinte, trinta, sei lá (TAPAJOS, 1977, p. 14).

A partir desta cena observo também como é mostrada a exterioridade da solidão sofrida pelos militantes nos aparelhos através do olhar do focalizador Ele. Tal solidão é observada como uma metáfora do inicio da decadência do movimento. Assim, a narrativa vai sendo descrita com a abertura de questionamentos como estes: por que lutamos? Que resultados terá a nossa luta contra o regime? Por que a luta só terá sentido com a morte dos revolucionários? E, esses questionamentos são lançados ao leitor como uma espécie de reflexão de análise sobre a ação do grupo armado e, ao mesmo tempo sobre a vida e o propósito que levou pessoas a abrirem mão de sua vida para lutarem contra o regime militar.

\footnotetext{
${ }^{3}$ Como o próprio nome sugere, à posição adotada pelo narrador para narrar a história, ao seu ponto de vista. O foco narrativo é um recurso utilizado pelo leitor para enquadrar a história de um determinado ângulo ou ponto de vista. (FRANCO, 2003, p. 41)

${ }^{4}$ Local onde os militantes se refugiavam para se esconder do militares, ou seja, é um esconderijo camuflado que servia para evitar que fossem presos pelos militares.
} 
As personagens centrais da ação da narrativa são Ele, Ela, o Venezuelano e Marta. O Venezuelano assume a liderança do grupo de estudantes, mas, é outro personagem, Ele, que assume um papel de grande importância no romance, pois, na medida em que o narrador direciona a focalização do discurso para este personagem, a forma cinematográfica é apropriada pela forma literária, particularmente quanto ao aspecto da focalização. Desse modo, a relação entre cinema e literatura se realiza aqui especificamente no nível da expressão. E, se propaga através dos diversos âmbitos significativos da narrativa do romance, muito especialmente o âmbito da relação entre ficção e história. Esse processo de apropriação tem como efeito entre outras coisas o de tornar mais evidente a impressão de realidade. Como num filme as imagens que vão se constituindo no romance adquirem maior capacidade de envolver e, em algumas situações, de chocar o receptor da obra.

Um exemplo de como se dá tal conexão é a cena em que através do olhar do personagem Ele o narrador descreve a decolagem de um avião:

o avião correu pela pista e ele, prendendo a respiração, observou a beleza daquela corrida, a força contida se transformando em vôo, a massa de alumínio vibrando, transfigurada numa ave feroz, de músculos distendidos, agressiva. Sentiu a mão de Marta em seu braço, a voz dela vindo de muito longe (TAPAJOS, 1977, p. 27).

Como dito anteriormente a impressão de realidade se torna mais densa a partir do recurso narrativo adotado. A descrição em detalhes de cenas com nitidez de cor e a descrição do espaço também se faz presente no fragmento abaixo:

A avenida ladeada de mangueiras, como um grande túnel, eu lembro. No meio da tarde, o sol filtrado pela copa das árvores, os poucos carros e as pessoas que passavam, sem pressa carregando calor. Casas antigas de grandes janelas abrindo diretamente para a rua, alguns jardins cercados por antigas grades, as grandes portas de madeira (TAPAJÒS, 1977, p. 28).

A riqueza de detalhes faz da leitura do romance uma "viagem" que se constitui como se fossem imagens cinematográficas, que tornam reconhecíveis, elementos de um bairro de Belém do Pará da década de 60: a Cidade Velha. É como se o leitor estivesse vendo através de um filme, a partir da demarcação de cada detalhe, dispostos e ordenados em seqüenciais cinematográficas. Tais seqüências são descrita na ordem linear dos acontecimentos descritos, ou seja, primeiro o formato da rua comparada a um túnel, segundo os objetos que a embelezavam como a copa das árvores dando uma outra tonalidade aos raios de sol, refletido nas pessoas que transitavam sem pressa a avenida ladeada composta de casas antigas ornamentadas de lindos jardins. 
Além disso, a idéia de fingimento, produto do flerte entre literatura e cinema é percebido no âmbito do discurso com o uso de uma espécie de vocativo: "Como em câmera lenta", como se observa a seguir:

Como em câmera lenta: ele percebeu que a rua estava bloqueada por uma batida policial. Olhou para os lados e percebeu que não havia por onde escapar: atrás, outros carros já paravam, cortando a possibilidade de manobrar e fugir pela contramão. Parou o carro lentamente. Um policial aproximou-se e pediu os documentos. Ele os entregou; o policial; o policial examinou-os lentamente. Estavam em ordem. Com os documentos nas mãos, o policial deu a volta no carro, olhou pela janela onde ela estava, examinando o interior do carro para ver se havia algo de suspeito. Ela sorriu timidamente, como que acanhada com o exame. No banco traseiro, um outro companheiro segurava uma maleta escura; o policial pediu para ver o que tinha na maleta e na maleta tinha uma metralhadora; ela se voltou para trás. Sua mão descreveu um longo arco em direção ao banco traseiro, mas interrompeu o gesto e desceu suavemente na abertura da bolsa, escondida entre os dois bancos da frente, um pouco atrás do freio de mão (TAPAJOS, 1977, p. 56-57).

A citação acima também nos mostra situações diretamente relacionadas aos elementos históricos igualmente apropriados pela narrativa literária. O fragmento resulta de uma rememoração do personagem Ele, relatando o dia em que um policial estava fazendo revista de rotina na rua e os militantes, sem saber da situação, são abordados e termina ocorrendo um violento confronto entre eles.

Desse modo, encontramos na narrativa de Em Câmera Lenta - além de aspectos relacionados às questões políticas do final dos anos 60, as ações armadas da guerrilha, a violência da repressão - a descrição da vida na clandestinidade: seu cotidiano, sua vida pessoal, seus amores, suas crenças, seus medos, seus gestos. Um olhar penetrante na vida e na intimidade dos jovens militantes que enfrentaram e se imolaram na guerra contra a ditadura militar. $\mathrm{O}$ uso da cinematografia é um recurso utilizado pelo autor para que o leitor "veja" de uma forma "psicoimagética" ${ }^{\prime 5}$ os acontecimentos narrados, assim a ficção aproxima-se do real, como observado no seguinte fragmento da narrativa:

Como em câmera lenta: o policial pediu para ver o que tinha na maleta e na maleta tinha uma metralhadora; ela se voltou para trás. Sua mão descreveu um longo, em direção ao banco traseiro, mas interrompeu o gesto e desceu suavemente na abertura da bolsa, escondida entre os dois bancos da frente, pouco atrás do freio de mão. O rosto impassível olhava para a maleta que o outro segurava, mas os dedos se fechavam sobre a coronha do revólver que estava na bolsa. E num movimento único, corpo, rosto e braço giravam

\footnotetext{
${ }^{5}$ É a partir desse termo, que defino a imagem mental que pode ser produzida pelo leitor durante a leitura do romance.
} 
novamente, o cabelo curto sublinhado o levantar da cabeça, os olhos, agora duros, apanhado de relance a imagem do policial que bloqueava a porta (TAPAJÒS, 1977. p. 25-26).

É a partir deste fragmento que observamos também que essa forma "psico-imagética" se funde aos mecanismos de punição e vigília, descritas por Foucault, "o terror enquanto suporte do exemplo: medo físico, pavor coletivo, imagens que devem ser grafadas na memória dos espectadores, como a marca na face ou no membro do condenado" (FOUCAULT, 2008. p. 91). Os dispositivos de repressão se destacam no romance de Renato Tapajós, porque os acontecimentos narrados vão se tornando mais próximos da imaginação do leitor, aproximando-o do que realmente aconteceu em um dado momento da história do país.

\section{Considerações finais}

Assim, utilizando aspectos cinematográficos o autor apresenta a visão ficcional através da qual a linguagem literária, ao flertar com a linguagem cinematográfica, trás a tona um conjunto de aspectos que podem ser compreendidos como próprios dos dispositivos de repressão ${ }^{6}$. Essa proximidade entre literatura e cinema visa, entre outros aspectos, a busca por uma sensação de realidade, mas como se trata da ficcionalização de um real insólito, pela catástrofe e pela imensidade do trauma que carrega, essa sensação de realidade é, ao mesmo tempo, rasurada pela fragmentação, esta produto das técnicas de narração e focalização anteriormente descritas. É nesse lusco-fusco, nessa fenda entre literatura e cinema, entre a sensação de realidade pretendida e ao mesmo tempo desfigurada que o discurso ficcional se impõe para mostrar o "jogo de rarefação" comum a todo discurso, segundo Foucault (1996, p. 70).

No romance de Tapajós tal processo de rarefação tem a função de re-fazer, tornar menos densa as imposições a que estão sujeitados certos personagens, não somente do ponto de vista da individualidade, como também da sua presença no tecido social da qual fazem parte. É dessa maneira que o personagem Ele se apropria do discurso da narrativa para falar em nome de uma sociedade que protesta contra o regime autoritário.

Ao se apropriar da narrativa enquanto voz, Ele provoca a diluição da densidade dos discursos envolvidos. Nesse processo, a linguagem cinematográfica é apropriada pela literatura.

\footnotetext{
${ }^{6}$ A tortura é antes de tudo um choque, uma surpresa, capaz de causar no indivíduo torturado medo, tendo ele a sensação o tempo todo de ser vigiado ou perseguido. (MATOSO, 1986. p. 11)
} 
Nesse processo, os discursos que precisam ser des-densificados estão rarefeitos, como observado na descrição do seguinte fragmento do romance:

E, no entanto, eu via tudo através de uma intensa elaboração: até as coisas mais banais tinham um encanto quase mágico. Não é a distancia nem o tempo. Era a maneira de ver, de revestir os gestos com uma gravidade solene e emprestar as vozes um eco literário [...] Toda beleza era triste por que não decifrada - a avenida, a praça e a praia, aparência de um mundo subterrâneo. Um mundo desconhecido, um mundo que eu precisava conhecer, para transformá-lo. Ou destruir-me. [...] (TAPAJÒS, 1977. p. 30-31).

Nesse sentido, a resistência é produto desse convite perscrutador que Ele faz ao leitor. Assim, Em Câmera lenta não é só uma narrativa de resistência, funciona também como "eco" das incertezas e ambigüidades dos militantes que de forma selvagem renunciaram as suas vidas, sua família, seus anseios, para lutarem por uma visão utópico-ideológica em que acreditavam naquela época.

\section{Referências}

AUMONT, Jacques. Dicionário teórico e critico de cinema. Tradução Eloisa Araújo Ribeiro. São Paulo: Papirus, 2003.

BONNICI, Thomas; ZOLIN, Lúcia Osana (Orgs). Teoria literária: abordagens históricas e tendências contemporâneas. Maringá: Eduem, 2003.

BOSI, A. Narrativa e Resistência. In: . Literatura e Resistência. São Paulo: Companhia das Letras, 2002, p. 118.

BUARQUE, Aurélio. Minidicionário da língua portuguesa. Coordenação de edição, Margarida dos Anjos e Marina Ferreira. 4a edição. Rio de Janeiro: Nova Fronteira, 2001.

FOUCAULT, Michel. A Ordem do Discurso. São Paulo: Edições Loyola, 1996

FOUCAULT, Michel. Vigiar e Punir: nascimento da prisão. Tradução de Raquel Ramalhete. $35^{\mathrm{a}}$ edição. Rio de Janeiro: Vozes, 2008. 288 p.

FOUlCALT, Michel. A Microfísica do Poder. Organização e tradução de Roberto Machado. Rio de janeiro: Edições Graal, 1979.

MATOSO, Glauco.O que é tortura. São Paulo: Nova cultural, 1986.

TAPAJÒS, Renato. Em Câmera Lenta: romance. 2a edição. São Paulo: Ed. Alfa-Omega, 1977. 